\title{
Diversity of fungi associated with rhizosphere of healthy and diseased garlic crop
}

\author{
BAIQ NURUL HIDAYAH ${ }^{1, \bullet}$, NANI HERAWATI ${ }^{1}$, AI ROSAH AISAH ${ }^{1}$, NITA RIZKY UTAMI ${ }^{2}$ \\ ${ }^{1}$ Institute for Assessment of Agricultural Technology of West Nusa Tenggara Province, Indonesian Agency for Agricultural Research and Development. \\ J1. Raya Peninjauan, Narmada, Lombok Barat 83371, West Nusa Tenggara, Indonesia. Tel./fax: +62-370-671312/+62-370-671620, \\ •email: baiqnurul@pertanian.go.id \\ ${ }^{2}$ Department of Biology, Faculty of Mathematics and Natural Sciences, Universitas Mataram. J1. Majapahit No. 62, Selaparang, Mataram 83126, West \\ Nusa Tenggara, Indonesia
}

Manuscript received: 6 January 2021. Revision accepted: 23 February 2021.

\begin{abstract}
Hidayah BN, Herawati N, Aisah AR, Utami NR. 2021. Diversity of fungi associated with rhizosphere of healthy and diseased garlic crop. Biodiversitas 22: 1433-1440. Garlic (Allium sativum L.) is an especially important horticultural crop in Indonesia because it is used as a cooking spice and for medicines and cosmetic ingredients. It is mostly grown in irrigated highlands; however Indonesian production is only supplying at most $17.5 \%$ of domestic demand. West Nusa Tenggara (WNT) Province is one of the largest garlicproducing regions in Indonesia. Currently, garlic cultivation in WNT Province is facing a problem of root rot disease. Therefore, it is necessary to investigate the fungi associated with garlic root rot disease. Research was conducted in June - September 2018 and samples were collected from Sembalun highlands (1200 m above sea level). Seventeen fungal isolates were collected from the rhizosphere of the garlic crops and fourteen of them were identified. The fungi isolated from the rhizosphere of healthy garlic crops were from the genus Aspergillus, Penicillium, and Paecilomyces. While the fungi isolated from the rhizosphere of diseased garlic crops were from the genus Aspergillus, Penicillium, Paecilomyces, Fusarium, and Phoma. The genus Fusarium and Phoma are well known as plant pathogens.
\end{abstract}

Keywords: Disease, fungi, garlic, roots rot.

\section{INTRODUCTION}

Microorganisms play an important role in the soil ecosystem. Microorganisms in the soil are found in root (rhizosphere) and affect soil fertility because they play a role in the energy and nutrient cycles, act as decomposers, and determine soil health against diseases especially soilborne diseases. Microorganisms that inhabit the soil can be bacteria, fungi, algae, and protozoa (Rao 1994; Adawiah 2016).

The rhizosphere is an area around plant roots that is affected by root activity and is rich in microorganisms. The study of the rhizosphere is closely related to the anatomy and structure of roots, which play a major role through exudates and other root deposits. A rhizosphere is a place for soil microbial interactions. The regions of the rhizosphere are very different from adjacent soil. Microbe populations are very large in the rhizosphere, often in different quality and quantity from different regions. The high microbial population is because the area is very rich in nutrients such as amino acids and sugars which are a source of nitrogen and carbon. The presence of nutrients is essential for the growth and multiplication of soil microbes, including root colonizers and antagonists. Some microbes found in the rhizosphere area are pathogenic to plants. These soil-borne pathogens grow and survive in the soil (Haryati 2012). Rhizosphere fungi are a group of microbes that have been reported to induce plant resistance to various diseases, both soil-borne and air-borne diseases (Hyakumachi and Kubota 2003; Purwantisari and Hastuti
2009). Rhizosphere fungi help plant growth through various mechanisms such as increased nutrient absorption, as biological control against pathogen attack, and also produce growth hormones for plants. Fungi that occupy the plant rhizosphere and live on plants as symbionts are known as endomycorrhizal and ectomycorrhizal fungi (Chanway 1997; Purwantisari and Hastuti 2009). Almost every type of plant has a variety of endophytic fungi; therefore, it is a high range of biodiversity (Purwantisari and Hastuti 2009). Endophytic fungi generally have mutualism symbiosis with their host plants. These fungi provide benefits to host plants in the form of increased growth rates, resistance to pests, diseases, and drought. Other species of soil fungi act as plant pathogens (Tanaka et al. 1999, Purwantisari and Hastuti 2009).

Garlic (Allium sativum L.) is a horticultural plant of very high economic value. It is the $14^{\text {th }}$ most important vegetable crop worldwide and the second most consumed plant of the Allium genus worldwide. Garlic is an especially important horticultural product in Indonesia because it is used as a cooking spice and for medicines and cosmetic ingredients. West Nusa Tenggara (WNT) Province is one of the largest garlic-producing regions in Indonesia. Garlic is mostly grown in irrigated highlands; however Indonesian production is very limited and only supplies at most $17.5 \%$ of domestic demand (Centre for Statistical Bureau 2019). Currently, garlic cultivation in the WNT Province is facing a problem of root rot disease. This study aims to identify fungi associated with healthy and diseased roots of garlic crops in the highlands of Sembalun, East Lombok, Indonesia. 


\section{MATERIALS AND METHODS}

\section{Survey and sampling location}

This research was conducted in June - September 2018. Rhizosphere soil samples were collected in the Sembalun highlands, Eastern Lombok, WNT Province of Indonesia (Figure 1). The samples were determined by purposive sampling. The field criteria used for this study were 2month-old crops that were healthy earlier and later attacked by fungi that caused pink root rot disease. Two types of soil samples were taken: garlic rhizosphere soil not affected by disease and garlic rhizosphere soil affected by disease (Figure 2).

Laboratory analysis was conducted at the Biology Laboratory, Faculty of Mathematics and Natural Sciences, Mataram University. Equipment used were: Petri dishes, Erlenmeyer flasks, autoclave, incubator, beaker, hoses, macro pipette, dropper pipette, pipette tips, Bunsen burner, test tubes, sterile cotton stick, ruler, laminar flow cabinet, hot plate, stirrer, analytical scales, test tube racks, measuring cups, scissors, tweezers, filters, and evaporators. Materials used were: soil and roots of garlic, potato dextrose agar (PDA), distilled water, cotton, tissue, 70\% alcohol, paper labels, $96 \%$ ethanol, physiological $\mathrm{NaCl}$ solution, corn paper, wrapping paper, filter paper, chloramphenicol as an antibiotic, and aluminum foil. The research equipment was sterilized at a temperature of $121^{\circ} \mathrm{C}$ for about 15 minutes.

\section{Preparation of potato dextrose agar (PDA) media}

Potato Dextrose Agar media was prepared by dissolving $60 \mathrm{~mL}$ of potato extract, $6 \mathrm{~g}$ glucose, and $6 \mathrm{~g}$ agar in 240 $\mathrm{mL}$ distilled water. The media was sterilized by autoclave for $15 \mathrm{~min}$ at $121^{\circ} \mathrm{C}$ temperature.
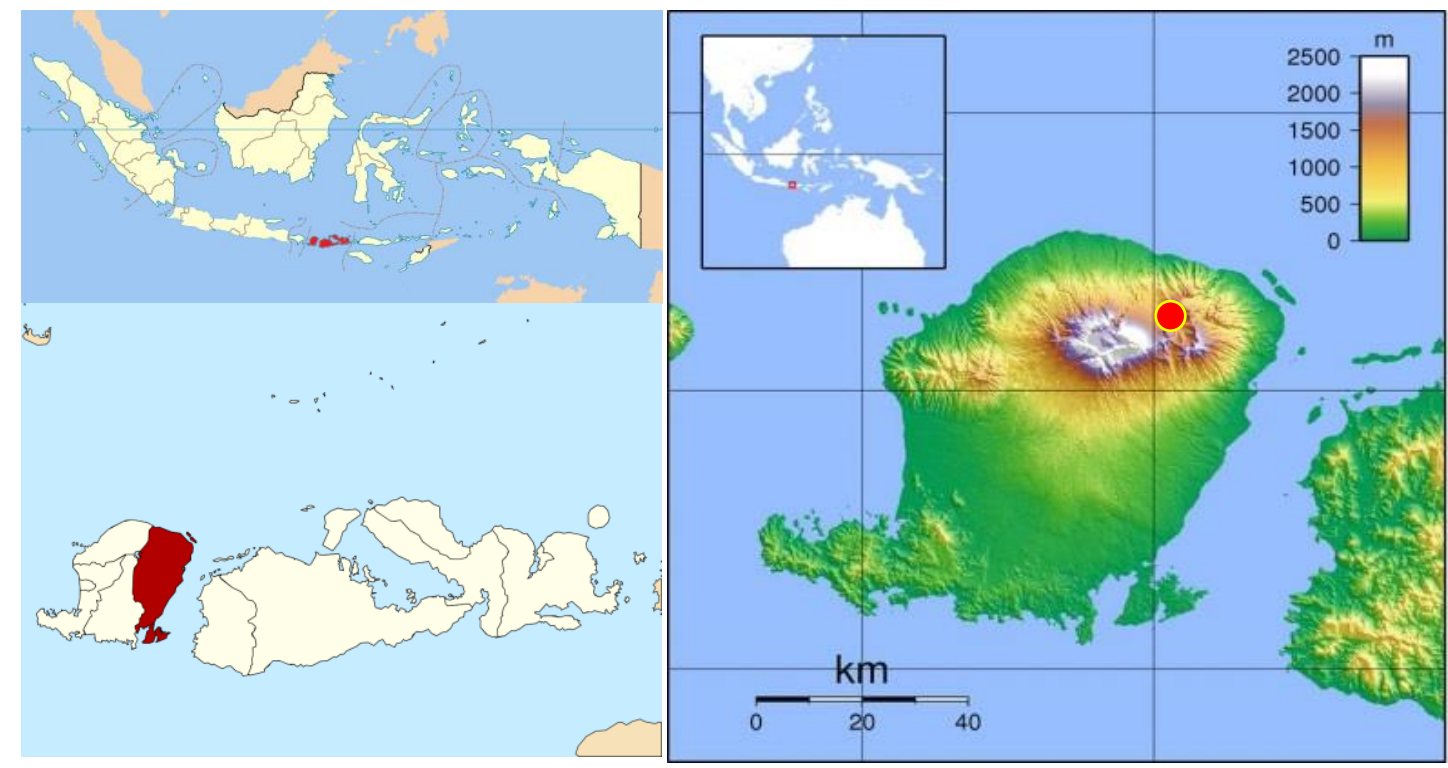

Figure 1. Map of Lombok Island, Indonesia: Red dots on the upper part of island showing the sampling sites in Sembalun highlands of Eastern Lombok District, West Nusa Tenggara Province, Indonesia

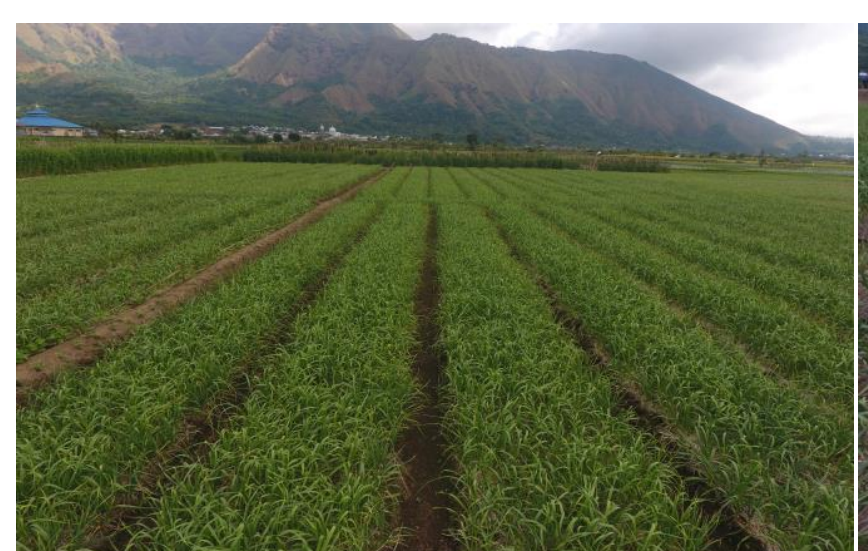

A

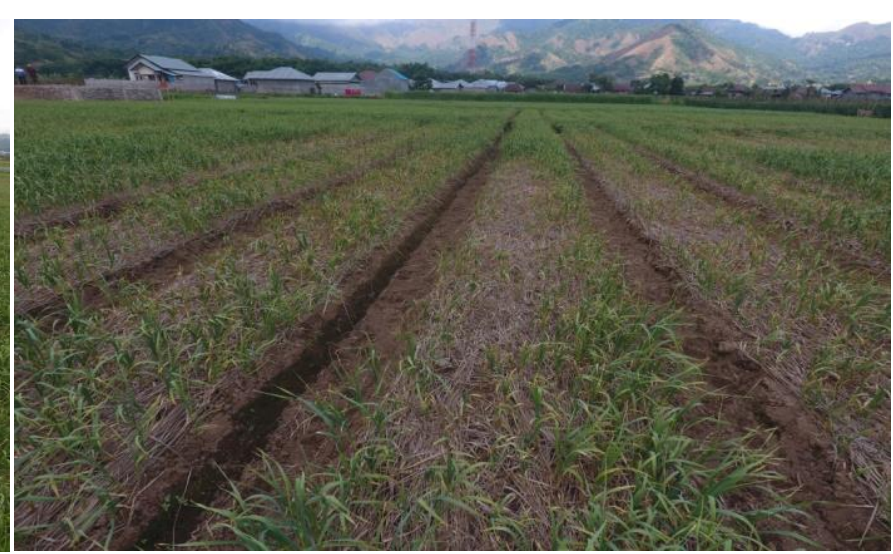

B

Figure 2. Two types of rhizosphere soils: A. Healthy garlic rhizosphere soil; B. Diseased garlic rhizosphere soil 


\section{Isolation of fungi from garlic rhizosphere}

The rhizosphere soil samples were taken from the soil attached to or around the root hairs of the garlic plants. Isolation of rhizosphere soil from garlic roots was carried out by a dilution method. One gram of rhizosphere soil was dissolved in physiological $\mathrm{NaCl}$ in the first test tube and vortexed until homogeneous. Then $1 \mathrm{~mL}$ of this rhizosphere soil suspension from the first tube was transferred to the second test tube to obtain a $10^{-2}$ dilution. Dilution process was carried out in the same way until $10^{-5}$ dilution was achieved. Then $0.1 \mathrm{~mL}$ suspension of $10^{-3}$ and $10^{-5}$ dilution was plated in petri dish containing PDA media. PDA media containing rhizosphere fungi were incubated for 24 hours at room temperature. Every single colony that grew then was purified. A pure culture of each fungus was maintained on PDA for identification purposes (Wain-Tassi et al. 2012).

\section{Fungal isolate purification and characterization}

Fungal isolates were purified by obtaining spores or mycelium and then isolate on PDA media. Incubation was carried out at room temperature for 1-3 days. Identification was carried out by observing morphological characteristics of colony growth, colony color, insulation on hyphae, color, and shape of spores and conidiophores. The books used to identify the colonies were: Barnett (1962), Barnett and Hunter (1998), Hanlin (1990, 1998), and Seifert et al. (2011).

\section{RESULTS AND DISCUSSION}

\section{Isolation and identification of fungi}

The identification of several fungal isolates was based on macroscopic and microscopic observations using 40x magnifications. Result of macroscopic identification showed that ten fungal isolates were found in the rhizosphere of healthy garlic crops and seven fungal isolates from the rhizosphere of diseased garlic crops. General characteristics of fungi isolated from the rhizosphere of healthy and diseased garlic crops can be seen in Tables 1 and 2. Tables 1 and 2 showed that, of the seventeen isolates, fourteen were identified to genus level. In the rhizosphere of diseased garlic plants, the fungi belonged to the genus Aspergillus, Penicillium, Paecilomyces, Fusarium, and Phoma. While the fungi isolated from the rhizosphere of healthy garlic plants belonged to three genera Aspergillus, Penicillium, and Paecilomyces.

In the Sembalun highlands, seventeen fungal isolates were found in the crop rhizosphere. This location is in the mountain areas therefore tends to be fertile, natural, and high number of microbial populations. The higher the soil microbial population, the higher the biochemical activity in the soil and the higher the soil quality index. Soil microbial populations that are not pathogenic are also considered an indicator of environmentally friendly agricultural technology (Saraswati and Sumarno 2008; Noerfitryani 2018). Saprotrophic fungi in the rhizosphere contribute to plant mineral nutrition (Baum and Hrynkiewicz 2006; Noerfitryani 2018).

Tabel 1. Characteristics of fungi isolated from rhizosphere of healthy garlic crop

\begin{tabular}{|c|c|c|c|c|c|}
\hline \multirow{2}{*}{ Isolate } & \multicolumn{2}{|r|}{ Surface } & \multirow{2}{*}{$\begin{array}{c}\text { Hyphae with } \\
\text { septate / not }\end{array}$} & \multirow{2}{*}{ Conidia } & \multirow{2}{*}{ Genus } \\
\hline & Shape & Color & & & \\
\hline HG 1 & Round /graduated circle & Green & Septate & Round & Aspergillus \\
\hline HG 2 & Round & Brown & Septate & Round & Aspergillus \\
\hline HG 3 & Round & Gray with a white center and edges & Septate & Round & Penicillium \\
\hline HG 4 & Round & Greenish gray & Septate & Round & Aspergillus \\
\hline HG 5 & Round & White & & Round & Paecilomyces \\
\hline HG 6 & Round & White like cotton & Septate & Round & Paecilomyces \\
\hline HG 7 & Round & Gray with white border & Septate & Round & Aspergillus \\
\hline
\end{tabular}

Note: HG: Isolate from the rhizosphere of healthy garlic crop

Tabel 2. Characteristics of fungi isolated from rhizosphere of diseased garlic crop

\begin{tabular}{|c|c|c|c|c|c|}
\hline \multirow{2}{*}{ Isolate } & \multicolumn{2}{|r|}{ Surface } & \multirow{2}{*}{$\begin{array}{l}\text { Hyphae with } \\
\text { septate / not }\end{array}$} & \multirow{2}{*}{ Conidia } & \multirow[b]{2}{*}{ Genus } \\
\hline & Shape & Color & & & \\
\hline DG 1 & Round & White with black on top & Septate & Fruits bodies like brooms with round conidia & Penicillium \\
\hline DG 2 & Round & White with red on top & Septate & Round & Phoma \\
\hline DG 3 & Round & Gray & Septate & - & Unknown \\
\hline DG 4 & Round & Gray black & Septate & - & Unknown \\
\hline DG 5 & Round & Black / gray edge & Septate & Round & Unknown \\
\hline DG 6 & Round & Gray pink & Septate & Round & Aspergillus \\
\hline DG 7 & Round & White like cotton & Septate & Fruits bodies like brooms with round conidia & Penicillium \\
\hline DG 8 & Round & White like cotton & Septate & Round at the end of the sterigma & Paecilomyces \\
\hline DG 9 & Round & Black & Septate & Crescent shape, slightly pointed tip & Fusarium \\
\hline DG 10 & Round & Yellowish-brown & Septate & Tiny little round together & Aspergillus \\
\hline
\end{tabular}

Note: DG: Isolates from the rhizosphere of diseased garlic crop 


\section{The genus of Aspergillus}

Aspergillus is a fungus that belongs to the Ascomycetes class which can be found everywhere in nature. It grows as a saprophyte in decaying plants and is also present in soil, organic dust, food and is a common contaminant found in laboratory hospitals. Aspergillus is a fungus that forms long, branched filaments and in the culture, medium forms mycelia and conidiospores. Aspergillus reproduces by the formation of hyphae or shoots and produces spore-forming conidiophores (Crystovel 2016).

The characteristics of Aspergillus are having septate hyphae and branched mycelium, while the hyphae that appear above the surface are fertile hyphae. Conidiophores are septate or nonseptate, upright, simple, radiating from the tip or the entire surface. At the end of the hypha a bubble appears, out of this bubble, the sterigma appears. Conidium appear on sterigma are arranged sequentially to resemble a string of pearls (Figure 3 ). Conidia are generally black, brown, and dark yellow color. On PDA media, colonies were round, light green to dark green, brown, and black color. Microscopically, conidia were round with septate hyphae (Barnett and Hunter 1998; Crystovel 2016).
Aspergillus is a fungus that is commonly found in soil, grows quickly, and is antagonistic to other fungi. The antagonistic mechanism of the fungus occurs by means of competition, mycoparasitic, and antibiosis. The culture can be obtained by isolating it from the soil (Abadi 2003; Adawiah 2016). Aspergillus produces the antimicrobial compounds mevionin and aspersillin (Gandjar et al. 2006). According to Dwijoseputro (1978) in Adawiah 2016, Aspergillus can play a role in anchoring free $\mathrm{N}$ from the air and dissolving phosphate in the soil that can be used as organic nutrients by crops.

Another study by Sopialena et al. (2018) found that Aspergillus sp. and Fusarium sp. were represent a large part of endophytic fungi in tropical soil both in ramps and sloping/hilly areas in East Kalimantan, Indonesia. However, sloping/hilly area has higher diversity of endophytic fungi compared to ramps area. In addition, Nelly et al. (2019) reported that Aspergillus sp obtained from rhizosphere of maize plants has potential as entomopathogenic fungi toward Tenebrio molitor larvae.

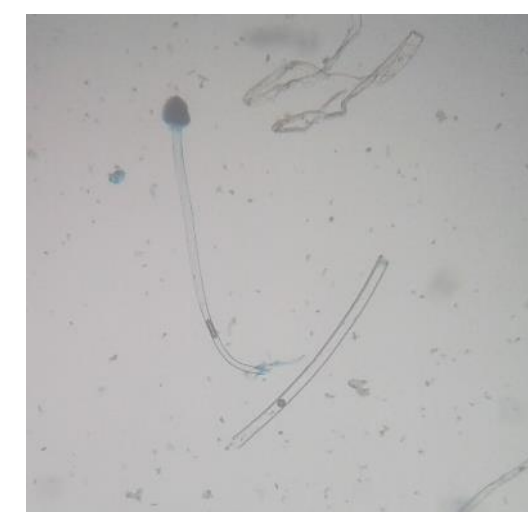

A

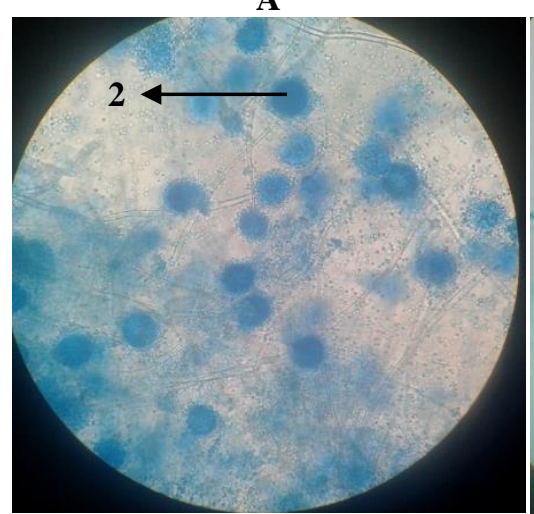

D

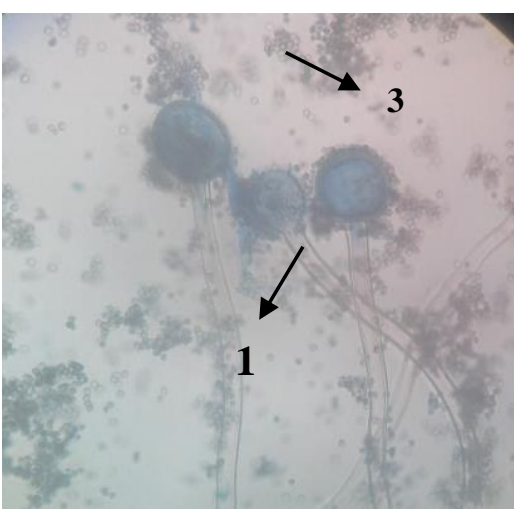

B

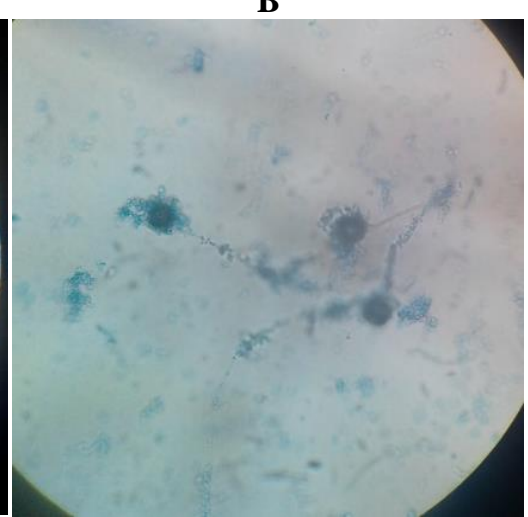

$\mathbf{E}$

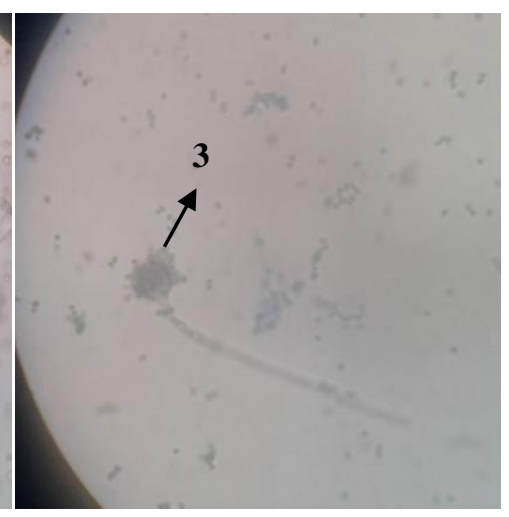

C

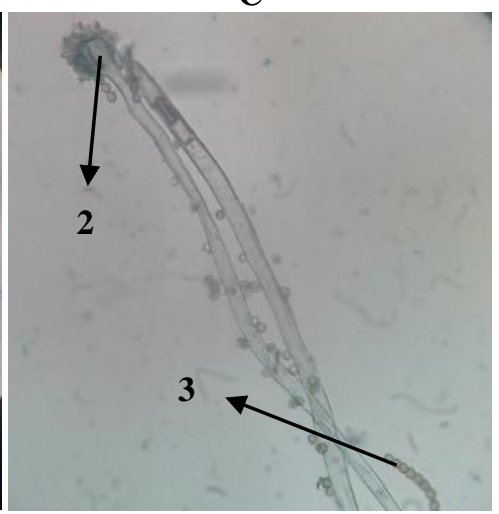

F

Figure 3. Conidiophore (1), sterigma (2) and conidia (3) isolate of HG 1 (A), HG 2 (B), HG 4 (C), HG 7 (D), DG 6 (E), and DG 10 (E) at 40x magnifications 


\section{The genus of Penicillium}

Penicillium is a genus of the order Hyphomycetes, phylum Ascomycota. Penicillium reproduces asexually by forming a conidium at the end of the hyphae. Penicillium is a soil fungus that exists in various types of soil. Colonies on PDA were round and white in color. The color of the young colony was white and the mature colony was dark green. The reverse side of the young colony was pinkywhite in color, while the reverse of the mature colony was green white. These morphological characteristics were in line with Penicillium isolated from rhizosphere of eggplant (Nuraini et al. 2017). Hyphae were septate, rounded conidia attached to conidiophores. Penicillium conidia resemble glass beads when viewed under a microscope (Figure 4).

Several species of Penicillium produce poisons in food/animal feed which cause poisoning in humans and animals (Tola and Kebede 2016). Penicillium is common found in soil, grows quickly, and is antagonistic to other fungi. The antagonistic mechanism of the fungus occurs by means of competition, mycoparasitic, and antibiosis. The culture can be obtained by isolating it from the ground (Abadi 2003). Nuraini et al. (2017) reported that Penicillium sp was capable of producing active compounds to inhibit growth of pathogenic fungi such as Fusarium oxysporum by an antibiosis mechanism.

\section{The genus of Paecilomyces}

Paecilomyces is a genus of fungi of the order Eurotiales, phylum Ascomycota. The genus Paecilomyces can be distinguished from the genus Penicillium although it is closely related, being from the same phylum. The difference is that Paecilomyces has different length and slender phialides and its colonies are usually never green. Colonies on PDA media were round and showed white mycelium. Conidia were round with septate hyphae (Figure 5). According to Crystovel (2016), the microscopic morphology of Paecilomyces variotii suggests chains of single-celled phialoconidia (ameroconidia) are produced in a basipetal succession of phialides. Conidia are formed in chains with the youngest at the base called basocatenate. The phialides have swollen bases that gradually taper towards the apex and can form a brush-like penicillus. Paecilomyces is a cosmopolitan filamentous fungus isolated from decaying soil and plant matter and is often associated with spoilage of food and cosmetic products (Urquhart et al. 2018).

Paecilomyces sp is a new chitinolytic fungal strain that produced extracellular chitinase activity (Homthong et al. 2016). Chitinases are produced as competition and defense mechanisms against other fungi or to colonize other arthropods including insects (entomopathogenic fungi). Paecilomyces sp also involved in mycoparasitism by mycoparasitic fungi (Homthong et al. 2016).
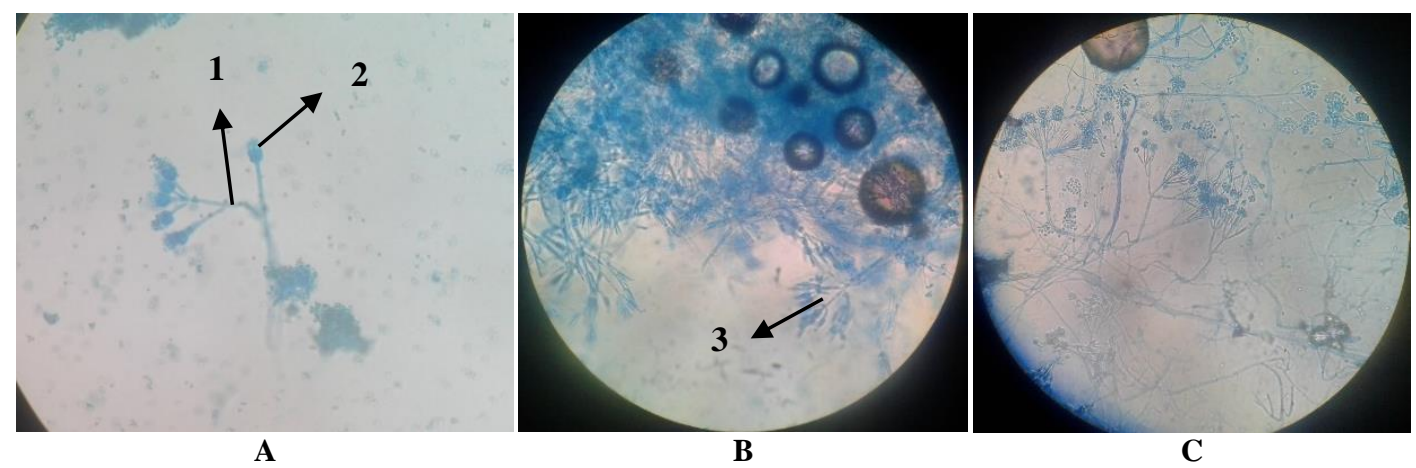

Figure 4. Septa (1), Conidia (2) and Sterigma (3) isolate of DG 1 (A), DG 3 (B) and HG 4 (C) at 40x magnifications.

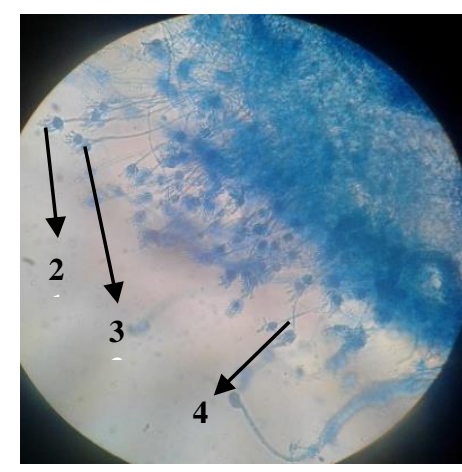

A

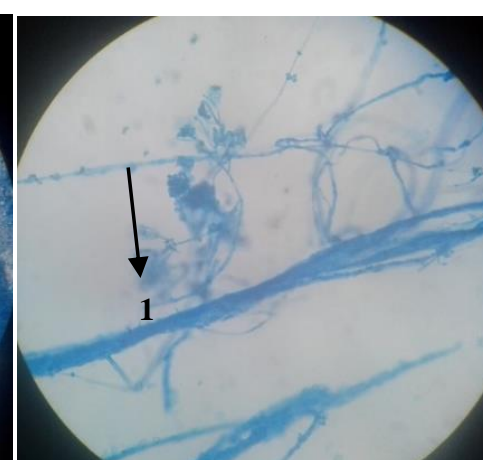

B

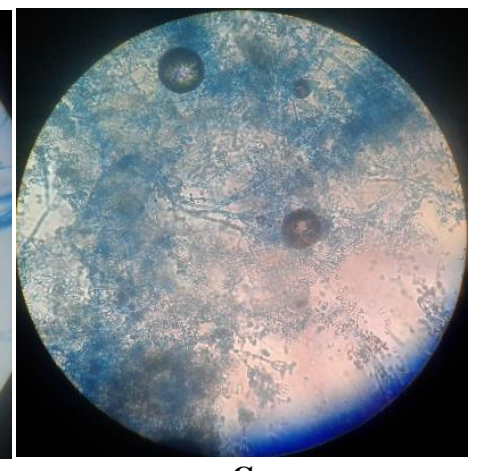

C

Figure 5. Septa (1), Conidia (2), Sterigma (3) Conidiophore (4) on the isolate of HG 5 (A), HG 6 (B), and DG 8 (C) at 40x magnifications 


\section{The genus of Fusarium}

Fusarium is a genus from the order Hypocreales, phylum Ascomycota. Fusarium is characterized as having a body structure in the form of branched, hyaline and septate mycelium with a diameter of 2 microns. Macroscopic features of Fusarium on PDA include black surface and round colonies. Microscopically, hyphae were septate, conidia having crescent-shaped with slightly pointed tip. Microconidia were formed from phialides, have a fine structure and a cylindrical shape, and consist of 2 or more cells that have thick cell walls (Figure 6). Microconidia generally consist of 1-3 cells, are round or cylindrical, and arranged into chains or clots (Hibbett 2007). The genus Fusarium consists of a high number of species that include plant pathogens, some of which cause disease in several agricultural crops. Mycotoxins produced by Fusarium can contaminate produce and so can also be harmful to humans and animals (Moretti 2009).

Fusarium is a very detrimental fungus because it can attack onions, chilies and other crops, from germination to maturity (Mishra et al. 2014). Although known primarily as soil-borne pathogens, this fungus can also infect, through wounds, other organs such as stems, leaves, flowers, and fruits. Apart from transmission of disease from spores found in the soil, infection can also occur through spores carried by wind and water (Adawiah 2016).

\section{The genus of Phoma}

Phoma is a genus the order Pleosporales, phylum Ascomycota. Members of this genus are characterized by colorless and unicellular spores. Macroscopic morphological characteristics of Phoma on PDA media include white surface with red spots and round colony. Microscopically, conidia were round, with septic hyphae (Figure 7B). Pycnidia are black in color and depressed on host tissue. The Phoma species are ubiquitous and common inhabitants of the soil. Species of the genus Phoma can periodically infect plants by causing root infections and various blotches. In addition, Phoma species have also been reported as invasive opportunistic pathogens in humans. Various agronomic plants have a significant range against species of the genus Phoma (Rai 2014). The pink root disease of garlic crops is a new threat to garlic cultivation in the Sembalun highlands, East Lombok.

The pink root disease in garlic crops is caused by soilinhabiting fungi, one of which is Phoma terrestris (Nischwith and Dhiman 2012). Garlic crop appeared stunted and foliage may show symptoms of nutrient deficiencies and stress. Severely affected seedlings may die. The outer bulb scales may become infected and develop pink or red blemishes or water-soaked rots (Figure 7A). Pink rot is known as severe disease in tropical and sub-tropical regions. This pathogen affects many crops, including eggplant, pepper, tomato, legumes, spinach, carrot, crucifers, and cucurbits. Even grain crops such as maize, millet, and sorghum (Koike et al. 2007).
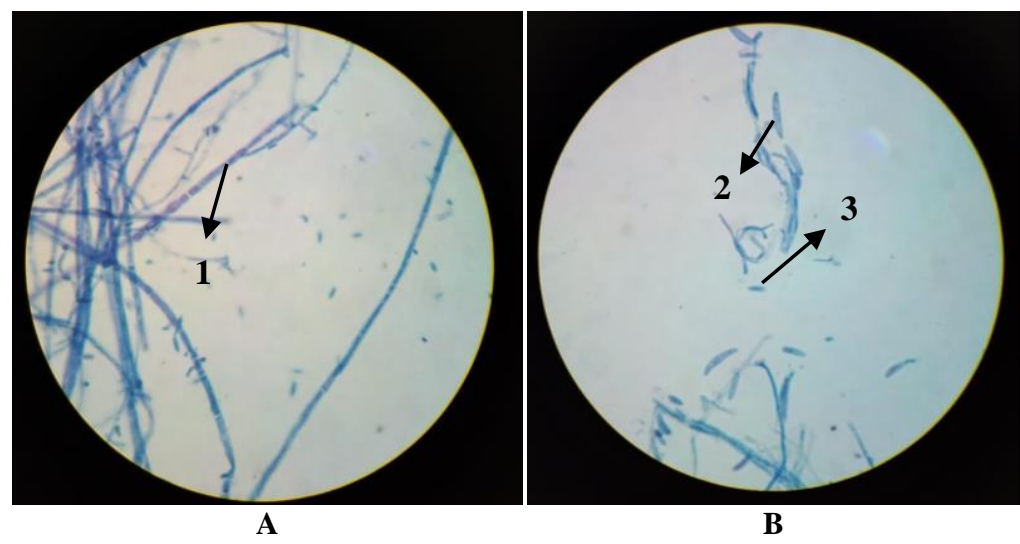

Figure 6. Septa (1), Macro conidia (2), Micro conidia (3) isolate of DG 9 (A, B) at 40x magnifications.

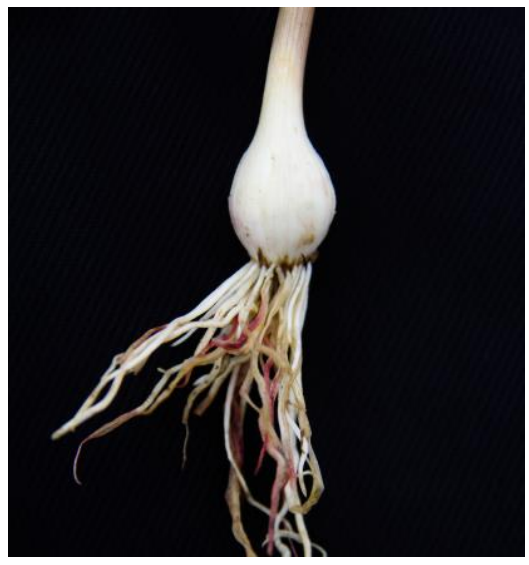

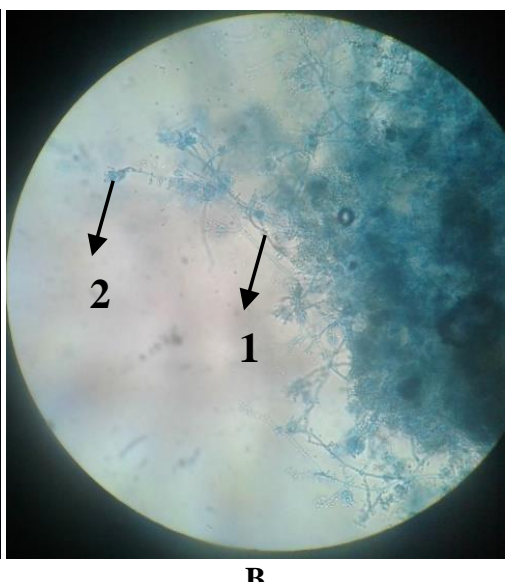

Figure 7. The pink root disease symptom in garlic root (A), Hyphae (1), Conidia (2) isolate of DG 2 (B) at 40x magnifications. 
Phoma sp also known to produced metabolites with herbicidal activity against bio indicated species of plants and weeds. It has a great potential for producing metabolites in the formulation of a bioherbicide for preemergence and post-emergence of weed as Bidens pilosa, Conyza canadensis, and Amaranthus retroflexus (Todero et al. 2018).

In conclusion, fourteen fungal isolates out of seventeen were identified at the genus level. The fungi found in diseased garlic crop rhizosphere were of the five genera Aspergillus, Penicillium, Paecilomyces, Fusarium, and Phoma. While in the rhizosphere soil of healthy garlic crops, fungi belonging to the genera Aspergillus, Penicillium, and Paecilomyces. Each genus has its own role for the environment, both beneficial and detrimental. The fungi harmful to the garlic crops are from the genus of Fusarium and Phoma. It is thought to be the Fusarium oxysporum and Phoma terestris species that causes pink root rot. For further research, it is suggested that the fungi isolated should be identified at the species level using molecular characterization and exploring the controlling strategies of the diseases.

\section{ACKNOWLEDGEMENTS}

These findings were based on the project entitled "Low input cultivation packages on garlic in West Nusa Tenggara Province of Indonesia" through the 2018 annual budget of the Institute for Assessment of Agricultural Technology (IAAT), West Nusa Tenggara Province, Indonesia. All authors were contributed equally in publishing this paper. We thank to Dr. Ir. M. Saleh Mokhtar, MP., director of IAAT West Nusa Tenggara Province during the period of 2016-2018 for his support. We thank Lalu Onang Tunggul Wijaya for his technical assistance in the field.

\section{REFERENCES}

Abadi AL. 2003. Ilmu Penyakit Tumbuhan. Bayu Media Publishing, Malang. [Indonesian]

Adawiah PR. 2016. Isolasi dan Identifikasi Cendawan Indigenous Rhizosfer Tanaman Kentang (Solanum tuberosum L.) di Buluballea Kelurahan Pattappang Kecamatan Tinggi Moncong, Kabupaten Gowa. [Thesis]. UIN Alauddin, Makassar. [Indonesian]

Baum C, Hrynkiewicz K. 2006. Clonal and seasonal shifts in communities of saprotrophic microfungi and soil enzyme activities in the mycorrhizosphere of Salix spp. J Plant Nutr 169: 481-487. DOI: 10.1002/jpln.200521922

Barnett HL. 1962. Illustrated Genera of Imperfect Fungi, $2^{\text {nd }}$ ed. Burgess Publishing Company, Minneapolis.

Barnett HL and Hunter BB. 1998. Illustrated Genera of Imperfect Fungi, Fourth Edition. APS Press, Minnesota.

Centre of Statistical Bureau 2019. Indonesia in Figures. Centre of Statistical Bureau, Republic of Indonesia, Jakarta. [Indonesian]

Chanway CP. 1997. Inoculation of tree roots with plant growth-promoting bacteria: an emerging technology for reforestation. For Sci 43: 96112. DOI: $10.1093 /$ forestscience/43.1.99

Crystovel JP. 2016. Mikologi Tanaman: Penicillium Peacilomyces Aspergillus. Universitas Padjadjaran, Sumedang. [Indonesian]

Dwidjoseputro. 1978. Pengantar Mikologi. Penerbit Alumni, Bandung. [Indonesian]
Gandjar I, Robert AS, Karin van den TV, Arianti O, Imam S. 1999. Pengenalan Kapang Tropik Umum. Yayasan Obor Indonesia, Jakarta. [Indonesian]

Hanlin RT. 1990. Illustrated Genera of Ascomycetes, Volume I. APS Press, Minnesota.

Hanlin RT. 1998. Combined Keys to Illustrated Genera of Ascomycetes, Volume I \& II. APS Press, Minnesota.

Haryati FS. 2012. Analisis Bakteri Rizosfer Tanpa Pengkulturan dengan PCR-RISA: Hubungannya dengan Kesupresifan Tanah Terhadap Busuk Pangkal Bawang Putih. [Dissertation]. Surakarta. Universitas Sebelas Maret. [Indonesian]

Hibbett. 2007. A higher-level phylogenetic classification of the fungi. Microb Res 22: 509-547. DOI: 10.1016/j.mycres.2007.03.004.

Homthong M, Kubera A, Srihuttagum M, Hongtrakul V. 2016. Isolation and characterization of chitinase from soil fungi, Paecilomyces sp. Agrocult Nat Res 50: 232-242. DOI: 10.1016/j.anres.2015.09.005.

Hyakumachi M, Kubota M. 2003. Fungi as plant growth promoter and disease suppressor. In: Fungal Biotechnology in Agricultural, Food and Environmental Application. Arora DK. (eds) Marcel Dekker.

Koike ST, Gladders P, Paulus AO. 2007. Vegetable Diseases: A Colour Handbook. Manson Publishing, London.

Moretti AN. 2009. Taxonomy of Fusarium genus, a continuous fight between lumpers and spiltters. Proc Nat Sci Matica Srpska Novi Sad 117: 7-13. DOI: 10.2298/ZMSPN0917007M.

Mishra RK, Jaiswal RK, Kumar D, Saabale PR, Singh A. 2014. Management of major diseases and insect pests of onion and garlic: a comprehensive review. J Plant Breed Crop Sci 6 (11): 160-170. DOI: 10.5897/JPBCS2014.0467

Nelly N, Syahrawati MY, Hamid H, Habazar T, Gusnia DN. 2019. Diversity and characterization of entomopathogenic fungi from rhizosphere of maize plants as potential biological control agents. Biodiversitas 20: 1435-1441. DOI: 10.13057/biodiv/d200536.

Nischwitz C, Dhiman C. 2012. Pink Root of Onion. Utah State University Extension and Utah Plant Pest Diagnostic Laboratory, Logan, UT.

Noerfitryani H. 2018. Inventarisasi Jenis-jenis Cendawan pada Rhizosfer Pertanaman Padi. Jurnal Galung Tropika 7 (1): 11-21. DOI: 10.31850/jgt.v7i1.282. [Indonesian]

Nuraini FR, Setyaningsih R, Susilowati A. 2017. Screening and characterization of endophytic fungi as antagonistic agents toward Fusarium oxysporum on eggplant (Solanum melongena). Biodiversitas 18: 1377-1384. DOI: 10.13057/biodiv/d180413.

Saraswati R. and Sumarno. 2008. Pemanfaatan mikroba penyubur tanah sebagai komponen teknologi pertanian. Iptek Tanaman Pangan 3 (1): 41-68. [Indonesian]

Seifert K, Morgan-Jones G, Gams W, Kendrick B. 2011. The Genera of Hyphomycetes. CBS-KNAW Fungal Biodiversity Centre, Netherlands.

Sopialena, Suyadi, Sahil M, Nurdiana J. 2018. The diversity of endophytic fungi associated with Piper nigrum in the tropical areas: A recent study from Kutai Kartanegara, Indonesia. Biodiversitas 19: 20282034. DOI: 10.13057/biodiv/d190607.

Tanaka M, Sukiman H, Takebayashi M, Saito K, Suto M, Prana MS, and Tomita F. 1999. Isolation, screening, and phylogenetic identification of endophytic plants in Hokkaido Japan and Java Indonesia. Microb Environ 14 (4): 237-241. DOI: 10.1264/jsme2.14.237.

Todero I, Confortin TC, Luft L, Brun T, Ugalde GA, de Almeida TC, Arnemann JA, Zabot GL, Mazutti MA. 2018. Formulation of bioherbicide with metabolites from Phoma sp. Scientia Horticulturae 241: 285-292. DOI: 10.1016/j.scienta.2018.07.009.

Tola M. \& Kebede B. 2016. Occurrence, Importance, and Control of Mycotoxins: A Review. Cogent Food and Agriculture 2: 1191103. DOI: 10.1080/23311932.2016.1191103.

Urquhart AS, Mondo SJ, Makela MR, Hane JK, Wiebenga A, He G, Mihaltcheva S, Pangilinan J, Lipzen A, Barry K, de Vries RP, Grigoriev IV, Idnurm A. 2018. Genomic and genetic insight into a cosmopolitan fungus, Paecilomyces variotii (Eurotiales). Front Microbiol 9: 3058. DOI: 10.3389/fmicb.2018.03058

Purwantisari S, Hastuti RB. 2009. Isolasi dan identifikasi jamur indigenous rhizosfer tanaman kentang dari lahan pertanian kentang organik di Desa Pakis. Magelang. Bioma 11 (2): 45-53. DOI: 10.14710/bioma.11.2.45-53. [Indonesian]

Rao S. 1994. Mikroorganisme Tanah dan Pertumbuhan Tanaman. UI Press, Jakarta. [Indonesian] 
Rai MK. 2014. Advances in taxonomy of Genus Phoma: polyphyletic nature and role of phenotypic traits and molecular systematics. Indian J Microbiol 54: 123-128. DOI: 10.1007/s12088-013-0442-8
Wain-Tassi AL, dos Santos JF, de Cassia Panizzi R, Vieira RD. 2012 Soil-borne pathogens and electrical conductivity of soybean seeds. Scientia Agricola (Piracicaba, Braz) 69 (1): 19-25. DOI: 10.1590/S0103-90162012000100004. 